\title{
The role of context in interpreting linguistic variables
}

\author{
Anna Babel ${ }^{*}$ \\ The Ohio State University, EE. UU.
}

\begin{abstract}
This article focuses on the use of contact features as social indexes in a Quechua-influenced variety of Spanish in central Bolivia. I suggest that context of use is important in producing social meaning, and indeed that context can redefine the indexical relationship between any particular sociolinguistic variable and its social referent or referents (Eckert 2008; Silverstein 2003). Spanish-Quechua contact features, acting as part of a system or pattern of enregistered features, do not have a single indexical meaning. Rather, their meaning is built through contrast to or congruence with the expected forms of speech for a speaker or group (Agha 2007; Babel 2011). These expected forms of speech are related to a listener's personal experience with the speaker over time, and with their conceptions of the types of speech that members of certain groups engage in. I argue that speakers form expectations about typical distributions of linguistic features, but that the interpretations of these patterns are highly context dependent and produced through microlevel interactional dynamics. Through these types of social negotiations, we can observe a system that produces meaning at a variety of scales and over a variety of dimensions, as part of a constantly shifting mosaic of linguistic performance.
\end{abstract}

Para correspondencia, dirigirse a: Dr. Anna M. Babel (babel.6@osu.edu), Department of Spanish and Portuguese, The Ohio State University, 298 Hagerty Hall, 1775 College Rd., Columbus, OH 43210, USA. 
Keywords: Bolivian Spanish, Andean Spanish, indexicality, enregisterment, language contact, context.

\section{LA IMPORTANCIA DEL CONTEXTO EN LA INTERPRETACIÓN DE LAS VARIANTES LINGÜÍSTICAS}

\section{Resumen}

Este artículo se enfoca en el uso de los rasgos de contacto como índices sociales en una variedad del español influenciado por el quechua en Bolivia central. Propongo que el contexto del uso es importante al producir el significado social de las variantes sociolingüísticas, además el contexto puede redefinir la relación indicial $^{1}$ entre cualquier variable sociolingüística determinada y su referente o referentes sociales (Eckert 2008; Silverstein 2003). Los rasgos de contacto quechua-español funcionan como parte de un sistema o de un patrón de rasgos registrados ${ }^{2}$, no tienen un único significado, sino que su significado se construye por un contraste o una semejanza con las formas esperadas del habla de una persona o de un grupo social (Agha 2007; Babel 2011). Estas formas "esperadas" del habla se relacionan con la experiencia personal del oyente con el hablante en el trascurso del tiempo, tanto como sus concepciones de las variedades del habla que utilizan los miembros de determinados grupos. Por ende, argumento que los hablantes forman expectativas acerca de las distribuciones típicas de los rasgos lingüísticos, pero que las interpretaciones de esos patrones dependen fundamentalmente de los contextos, y se producen a nivel de la micro-dinámica de las interacciones. A través de esta clase de negociaciones sociales podemos observar un sistema que da un significado a una gama de niveles y a varias dimensiones, como parte del mosaico dinámico de la actuación lingüística.

Palabras clave: español de Bolivia, español andino, indexicalidad, registro, contacto de lenguas, contexto.

Recibido: 10/04/14 Aceptado: 08/07/14

Indexical relationship.

Enregistered features. 


\section{INTRODUCTION ${ }^{3}$}

Language users' interpretation of linguistic features at the microinteractional level is built through contrast to and congruence with large-scale semiotic systems of interpretation. The interpretation of particular features always takes place against the backdrop of an understanding of typical patterns of interaction, not only at the community level, but also for social groups and even individuals. In this article, I describe the construction of social meaning in a Quechua-influenced Bolivian dialect of Spanish. In this context, the use of Quechua contact features gains meaning in concrete interactions by particular individuals as representatives of particular social groups. I demonstrate that the same contact features used by individuals identified with different groups results in differing social interpretations and characterizations of the speaker. This work contributes to the existing literature by complementing formal studies of language contact in the Andean region (e.g. Escobar 2000; Sánchez 2004) and by extending the literature on Bolivia, which has been relatively under-studied as a contact zone. Following Godenzzi $(2005,2011)$, this work brings a microcontextual perspective to existing work on sociolinguistics and language ideologies in the Andes (Albó 1970; Howard 2007).

Sociolinguists and linguistic anthropologists have long been involved in deciphering just how social and semiotic patterns are generated, how they shift, and how they change. Over the past forty years, critiques of variationist sociolinguistics have led to shifts in the focus of sociolinguistic research. Early variationist work linked linguistic variables to broad demographic categories (e.g. Labov 1972a; Labov 1972b); later work examined variables' realization in social networks (Milroy \& Milroy 1997). Still other studies have shown the ways in which linguistic variables participate in identity and social identification (Bucholtz \& Hall 2004; Eckert 2000; Kuipers 1998; Rampton 1995), and, more recently, the way that social structures, such as

\footnotetext{
3 My heartfelt thanks, first and foremost to the consultants who participated in this project, especially the Avila family; to the editors for bringing this volume together; to an anonymous reviewer for constructive comments on the manuscript; and to Mary Rose for her sharp editorial eye and suggestions on flow and clarity. Karen Lopez Alonso generously proofed and edited my Spanish abstract. Thanks to Sally Thomason, Bruce Mannheim, Robin Queen, Judy Irvine, and Steve Dworkin for their comments on an earlier version of this work. Parts of this research were funded by a National Science Foundation Graduate Research Fellowship, by the Rackham Graduate School of the University of Michigan, by the Ohio State University, and by the Freiburg Institute for Advanced Studies.
} 
“clan", are constructed through local practices (Stanford 2009). Linguistic behavior, it seems, is as fluid and context-dependent as other forms of social action.

Eckert (2012) suggests that sociolinguistics has developed in three "waves". The first wave includes quantitative variationist study of the relationship between sociolinguistic variables and social groups. This wave took for granted fixed, relatively static social groups and tried to establish statistical correlations between sociolinguistic variables and the speech of those groups. The second wave is an ethnographic approach, which takes the study of language as social practice, an approach that emphasizes the constructed nature of group-ness. The third wave, still in emergence, sees language as stylistic practice, in which variation is part of a social semiotic system that speakers use not just to reflect an identity, but to construct both that identity and the broader field of meaning (94). An important component of the third wave approach is the flexible system of indexical meaning that is captured in the concept of the indexical field (Eckert 2008). Sociolinguistic variables do not have a single meaning; rather, they may be interpreted in a variety of ways, based on the context in which they are used and who is listening. Likewise, demographic categories such as gender and social class are constructed, not predetermined (Eckert 2012).

Linguistic features are not only part of a language system; they are signs that link to systems of social interpretation and positioning. Agha $(2000 ; 2004 ; 2007)$ holds that the indexical processes of context-based and person-based variation are essentially related. He defines enregisterment as "processes whereby distinct forms of speech come to be socially recognized (or enregistered) as indexical of speaker attributes by a population of language speakers" (2005: 38). Registers of speech are composed of bundles of linguistic features that are associated with a particular semiotic cluster. Registers, then, are generated through a process that links forms of speech, for example, co-occurrence patterns, to particular types of people and situations. Speakers may shift rapidly through different registers as they reference a variety of styles or personae, or they may conform strictly to the conventions of a particular written or spoken genre. These practices, these choices, take on meaning only within the context of a particular social and semiotic system.

In the following sections, I show how the concepts of indexicality and enregisterment can be used to interpret the incidence of Quechua contact features in a variety of Andean Spanish spoken in Bolivia. I examine the way that co-occurrence patterns are contextualized through their relationships to social groups, settings, and personae. In previous work, I demonstrated that linguistic indexes are distributed in predictable ways across social contexts 
and that they are used in predictable patterns by different types of speakers (Babel 2010). These patterns are tendencies, not absolutes. Highly skilled speakers use contact features in novel and unexpected ways, and listeners take these tendencies into account when evaluating their interlocutors. Because of the social knowledge that people hold about surrounding patterns of speech, less proficient speakers' use of contact features may be categorized as "mistakes", while in the speech of more fluent language users the same feature may be evaluated as a "strategy". Listeners evaluate language use based on their expectations of co-occurrence patterns for particular speakers, in particular situations. I demonstrate this by analyzing evaluations of the use of contact features that are produced by speakers who belong to two different sociolinguistic categories, Spanish-dominant speakers from the local Santa Cruz valleys (vallunos) and Quechua-dominant migrants from the Western Bolivian highlands (collas). Quechua-dominant speakers are evaluated as less able speakers, undesirable neighbors, and unknowledgeable about the relevant context of speech. Spanish-dominant speakers, even when they use the same contact features, are framed as knowledgeable and deserving participants in the interactions that I observed.

In this article, I also draw on a body of existing sociolinguistic work on the languages of the Andes. Most of this literature focuses on Peru and in particular on large urban centers such as Lima and Cuzco. From a macrolinguistic perspective, it has been well established that Andean languages are generally stigmatized in relation to Spanish (Coronel-Molina \& Grabner-Coronel 2005; Howard 2007), Likewise, contact-influenced varieties of Spanish are less prestigious than elite varieties, which are spoken almost exclusively in urban contexts. However, there is variation within this generalization; Escobar demonstrates that Andean Spanish is not monolithic by identifying grammatical differences between L1 Quechua speakers and L1 Spanish speakers in Peru $(1988 ; 1992 ; 1994)$. De los Heros (1999) finds that although national prestige is centered in the upper-class Spanish variety spoken in Lima, regional elite standards are also highly rated in the regions in which they are used. From a different and wider theoretical perspective, Godenzzi (2005) demonstrates that in both historical and contemporary discourses, the use and interaction of language practices is fundamentally rooted in the exercise of power.

Early studies of Bolivian sociolinguistics typically take a dialectological or first wave variationist perspective. Albó (1970) demonstrates that language practices are closely related to social factors, and that the two are predictive of each other through an implicational scale. Gutiérrez Marrone (1980) links the use of particular types of language to social groups, such as "gente decente", "birlochos", "cholos", and "indios", and she notes that language 
mixture is associated with cholos, though she characterizes attitudes toward indigenous languages as ambivalent.

At a level of more detailed social and linguistic analysis, contact features have been shown to play a role in the construction of identity and stance. Escobar (1998) finds that stance and interpersonal relationships are a driving factor in the use of contact features borrowed from Quechua, such as the diminutive and the use of evidentials. De los Heros (2001) takes a step into the third wave in her close analysis of the sociolinguistics and pragmatics of gender in Lima and Cuzco, noting "Los individuos manipulan la lengua para construir su identidad de género. Ellos saben que la identidad se crea con una continua negociación en cada acto de participación social..."4. De los Heros (2008), analyzing the use of language in hair salons in Lima, finds differences in the use of contact features depending on the topic and the type of establishment. Zavala (2011) finds that students in Cuzco who show evidence of Quechua contact features in their speech are strongly stigmatized, and that they internalize this language attitude. Finally, in the context of migration, Ambadiang et al. (2009) find that young Ecuadorian migrants to Spain associate Ecuadorian Spanish strategies both with identity as an Ecuadorian and with a contrast between Ecuadorian politeness and Spanish rudeness. These studies take Quechua contact features of Andean Spanish to be tools that speakers use in social positioning.

Recent work has emphasized the role of language use in constructing urban spaces and identities. Godenzzi (2008) demonstrates that speakers use linguistic features of contact varieties of Spanish, among other linguistic resources, in order to construct the spatial organization of the city of Lima and their own place in it. Firestone (2013) demonstrates that migrant youth in Ayacucho use Quechua language and practices in order to construct an urban Andean identity. Firestone notes that Quechua and Spanish exist along a continuum in the context of Lima, an observation that echoes Pfänder (2009)'s characterization of the hybrid grammar of Quechua and Spanish in Cochabamba.

This article contributes to the existing literature in two ways. First, I turn the focus from Peru and urban centers to rural Bolivia, where Quechua contact features in Spanish are available as a resource for producing social categories at a local level. Secondly, this article draws on the aforementioned characterizations of Andean Spanish as a flexible and creative resource for

4 Individuals manipulate language to construct their gender identity. They know that identity is created through a constant negotiation in every act of social participation (translation A. Babel). 
social positioning, but turns the focus to the interpretation rather than the production of sociolinguistic indexes.

The main idea of this article is that meaning is produced in relationship with context, both social and linguistic. This claim is in line with existing work that views the creation of sociolinguistic meaning as a type of creative practice. However, it moves beyond existing work by examining linguistic features as part of an interrelated web or pattern of meaning. This pattern encompasses both a variety of sociolinguistic indexes and other ways of producing of social meaning, such as dress, migration history, and identification as a language speaker. I use contact features as a case study to gain a foothold, a point of entry, into this complex relationship. In the examples I examine from my data, the same contact features are interpreted differently when they are produced by speakers who identify with different social categories. Even when they use exactly the same contact features, women who are from the local area surrounding the Santa Cruz valleys (Valles Cruceños) and who identify as native Spanish-dominant speakers are evaluated favorably, while women who are Quechua-dominant and come from the Western highlands are evaluated negatively. These evaluations are in line with a group of beliefs, discourses, and practices that strongly differentiate between these two groups in the local context.

To interpret my data, I use the concepts of indexicality, enregisterment, and the semiotic field. Indexicality refers to the relationship between linguistic signs and particular social referents (Eckert 2008; Silverstein 2003). Linguistic signs are not neutral, but rather are linked to other social characteristics through indexical relationships. Enregisterment is a process by which language varieties and linguistic signs are linked to particular types of social figures or practices (Agha 2007). Because sociolinguistic indexes are linked to specific types of people through the process of enregisterment, the characteristics they evoke or refer to can be understood in different ways depending on the type of person who uses them. Finally, the semiotic field is an overarching structure that organizes social and linguistic practices into a coherent system of meaning. Both linguistic and non-linguistic material participates in a broader system of social meaning that constitutes the semiotic field.

\section{TOOLS AND METHODS}

I approach the class of enregistered features that I examine using close ethnographic and linguistic analysis. Ethnographically, I present each 
speaker as a member of a social group and in a particular speech situation. Linguistically, I focus on features that local language users understand to be typical of this contact variety of Spanish. Local language users link these contact features to a semiotic system that contrasts Spanish, youth, mestizo heritage, modernity, education, urban life, and masculinity with Quechua, tradition, indigeneity, rural areas, and uneducated older women.

The data come from a contact variety of Spanish spoken in central Bolivia, in a town that I identify by the pseudonym "Iscamayo". In this agricultural area, Quechua-dominant bilinguals from the western valleys and highlands (collas) historically have been and continue to be in close contact with Spanish-dominant speakers from the local Santa Cruz valleys (vallunos).

The data were collected from interviews, meetings, and conversations over an eleven-month period in 2008. I recorded two types of interviews: language ideologies interviews, to discuss ideas that people held about languages and ways of speaking; and kitchen practices interviews, to discuss cooking practices with women participating in a development project. In interviews, I attempted to direct the conversation by following a printed page of questions and placing the recorder in conspicuously plain view. The meetings were formal community meetings, usually of local political organizations, though I also recorded mothers' club meetings, parent-teacher organizations, and other meeting contexts such as a baptismal class offered by local Catholic nuns. Speech that I obtained during meetings tended to be formal and on-the-record. I usually requested permission to record during the meeting and then sat near the head table to record the speech produced by the group's officers. The conversations were much more varied in character than interviews or meetings but were always undirected conversations generally recorded at the participants' home with people who were very comfortable with me. Unlike interviews, I was never the only or even the primary interlocutor in conversations.

For my analysis, I selected the second ten minutes of each recording for transcription. When the second ten minutes was not appropriate for transcription due to noise or other factors, I moved to the third ten minutes. Recordings that did not meet the twenty-minute threshold were not analyzed for this corpus. In all, I had recordings and transcriptions of 16 meetings, 16 interviews, and 16 conversations. The data discussed here were taken from these 480 minutes of transcribed recordings. I gathered the data using a Marantz PMD-620 recorder, and I transcribed them in consultation with a native speaker, using Atlas.ti, a qualitative analysis software tool. A more detailed description of the methodology can be found in Babel (2010).

I had worked in the community for six years at the time of data collection, including several periods of long-term immersion. Many of my consultants 
were close friends or family members, and virtually all of them knew me quite well through work and kin links that I developed throughout my time in the field. Though their self-identification as Spanish-dominant or Quechuadominant speakers varied, the great majority of my consultants were native or very fluent speakers of Spanish. Each speaker is discussed in more detail in the Data section.

The speakers that I discuss here are all women. While I recorded both women and men during my fieldwork, I had richer, stronger, and more egalitarian relationships with women in my field site than with men due to local gender norms. Therefore, the bulk of my recordings, and often the most interesting data, come from talk with women. Because gender, through the filter of the particular conditions of my data collection, adds another dimension to variation, I decided to draw only from my conversations with women in order to make as close a comparison within these cases as is possible with data collected in recordings of natural events.

\section{THE SEMIOTIC SYSTEM}

In the Andes, Quechua and Spanish have been in contact for nearly five hundred years, and in the local valleys that include Iscamayo, they have been in contact since the early $17^{\text {th }}$ century. Due to this long-term contact and the persistence of large groups of Quechua speakers, especially in Bolivia, Quechua contact effects on Spanish have been demonstrated at every level of linguistic structure (Calvo Pérez 2000; de Granda 2001; Escobar 2000). However, Andean Spanish varies along social and geographical axes (Escobar 1988; Escobar 1994; Klee 1996), including the speaker's languagelearning history and identification as a language speaker (Howard 2007). In Bolivia, styles of speech reliably link speakers to particular towns, forming microdialects that people from the local area quickly recognize.

The contact features I discuss are among the most recognizable and least common features used in the Spanish of my field site. Speakers tend to be very conscious of them and to use them in parodies and jokes, as well as in natural discourse. They also carry a strong stigma (cf. Lipski 2004: 132). Nevertheless, they are employed under certain social conditions across social and linguistic groups.

I use the term semiotic field to describe a complex geography of social signification that encompasses not just language, but also styles of dress, 
political stances, gender expression, migration and residence patterns, and even emotions and affective stances. The semiotic field is an "umbrella" of meaning that enfolds but also structures the relationships of different kinds of social signs to each other. The things that my consultants do or say, and the ways that they do or say them, can be linked to different subsections of the broader semiotic field. Contact features, in general, are associated with a bundle of features that are grouped under the "traditional" semiotic complex, a complex that includes links to older people, women, and people from the countryside (see also Babel to appear-b). However, this general association does not always hold in the same way for all people or, indeed, for all contact features (Babel 2011). It is the context of use, and people's expectations of language users from particular social groups, that picks out a set of meanings based on language use in any particular discourse setting. This set of meanings depends greatly on experience with language and social groups and may not be identical for all listeners, though it is similar enough that we can observe large-scale patterns and areas of general consensus.

The contact features described here participate in a semiotic field linking them to a complex of features that includes traditional styles of dress (such as use of the pollera, a gathered skirt), and to Quechua-dominant speakers, the rural countryside, indigenous heritage, and individuals with little formal education. Under certain conditions, they may also be linked to hospitality, respect, and expressions of affect (anger, sorrow, empathy, humor, mocking). Contact features, then, participate in a pattern of enregisterment (Agha 2007; Babel 2011), in which they are linked to the speech of those most likely to have contact influence, such as older women, people from the rural countryside, and immigrants from the western highlands. These features tend to be used most often in informal, relaxed conversational contexts among family and friends. While many of Iscamayo's residents recognize and use contact features as markers of a distinct local identity, constant waves of migration produce a long-term language contact situation. In this context, social groups not only have different language abilities and histories, but also are understood to orient differently towards features associated with Quechua and speakers with significant contact influence. Thus, Quechuadominant immigrants with little experience with local Spanish are understood to use contact features because of interference from a first-language base. In contrast, Spanish-dominant speakers from the local area use many of the same features, but these are interpreted as markers of rurality or a traditional identity.

The social division between Quechua-dominant western highlanders and Spanish monolingual eastern lowlanders is pervasive and highly salient throughout Bolivia (Bergholdt 1999; Hurtado 2005; Stearman 1987). In the 
region of Iscamayo, lying as it does on the border between highlands and lowlands, people constantly reinforce this dichotomy even as they claim to stand outside it: "We are neither cambas nor collas". Many local people note, however, that historically the town and its surrounding areas have been populated by people from the west, often Quechua-dominant speakers. While Iscamayo maintains a strong identity as a Spanish-speaking town, and Quechua-speaking migrants usually shift to Spanish within a generation or two, there is persistent influence from Quechua in local speech patterns. Locals say that the town is dominated by collas, but many have encountered cambas only through their own migration to the eastern lowland city of Santa Cruz and surrounding areas. Therefore, the most relevant distinction for local people is not between cambas and collas, but between colla migrants and Spanish-dominant locals, who are often themselves the children of migrants. These Spanish-dominant locals identify themselves as vallunos, "valley people,' emphasizing their roots in the Santa Cruz valleys.

\section{CONTACT FEATURES}

Quechua contact features are some of the most salient linguistic characteristics that are associated with local speakers and styles of speech. In this article, I analyze the use of some of these contact features and compare their use across the two social groups, vallunos 'Spanish-dominant people from the local [Santa Cruz] valleys' and collas 'Quechua-dominant people from the western highlands.' A description of the contact features that I discuss in this article can be found in the following paragraphs.

Quechua has a very regular penultimate stress pattern. The default stress pattern in Spanish is also penultimate stress, but there are more exceptions in Spanish than are found in Quechua (Escobar 1976). Often, words without penultimate stress in normative Spanish are used with penultimate stress in the contact variety of Spanish spoken in Iscamayo as a way of invoking the traditional semiotic complex. For example, the proper name Ángela is pronounced as Angéla, or plátano 'banana' becomes platáno.

One of the most salient, most iconic markers of Quechua speakers in Spanish is the influence of the Quechua three-vowel system, $a, i$, $u$, with backed allophones in the context of uvular $q$ and glottalized consonants, on the Spanish five-vowel system $a, e, i, o, u$. Speakers tend to use vowel raising of $e$ and $o$ to $i$ and $u$, and they also hypercorrect, using vowel 
lowering of $i$ and $u$ to $e$ and $o$. This phenomenon affects Spanish-speakers as well as Quechua-speakers. For a discussion of this phenomenon, labeled "motosidad," see Cerrón-Palomino (2003: 37-64).

Both Spanish and Quechua tend to have CV syllable structure, but Quechua is much more regular; often, both Spanish-dominant and Quechuadominant speakers create CV syllable structure in Spanish diphthongs. For example, they insert a glide in the verb traer 'to bring,' making it trayer, or they change ie diphthongs to $e$, changing bien 'well' to ben .

Leveling irregularity in verb paradigms, such as the diphthongization in verbs like tiene 'he has' [from tener, becoming tene] and entiende 'he understands' [from entender, becoming entende], is a common L2 phenomenon. Because Quechua does not have a distinction between /e/ and $/ \mathrm{i} /$ in these contexts, these features are probably also related to phonological influence from the Quechua three-vowel system (Calvo Pérez 2008; Mendoza 2008).

Consonants also bear traces of Quechua contact. Because Quechua does not have contrastive voicing, $/ \beta /$ (orthographic $b$ or $v$ ) is often realized as [w] by speakers with contact influence. In addition, speakers commonly use a nonstandard realization of /f/ as a bilabial voiceless fricative [ $\varphi]$, or more accurately, $\left[\varphi^{\mathrm{w}}\right]$, with lip rounding. This allomorph of the labiodental /f/ also appears in rural varieties of archaic Spanish. While Quechua does not have a labiodental fricative, /f/ is usually borrowed into Quechua as / $\mathrm{p}^{\mathrm{h}} /$. It is possible that some degree of variation in /f/ comes from Quechua speakers, but it is at least as probable that it has an archaic Spanish source. This feature is strongly associated with orientation to a traditional, rural lifestyle and with Quechua-dominant speakers in contemporary Bolivia.

At the morphological level, nonstandard gender and number agreement is common in Andean varieties of Spanish (Sánchez 1996). Variable number and gender agreement, including variation in the interpretation of collective nouns, is often associated with speakers who have contact influence (Martínez 2009). An abundance of diminutives is typical of Andean Spanish, as it is of contact varieties of Spanish throughout Latin America (Escobar 1994). Prosodic influence from Quechua is also common (Muntendam 2011), and women with Quechua influence tend to speak in a higher phonetic register. Under certain circumstances, falsetto voice is utilized by both women and men (Albó 1970; Babel 2011).

At a lexical level, loanwords from Quechua, especially in toponyms, plants, animals, agriculture, cooking practices, child-raising, weaving, swear words, and nicknames are also commonly used by individuals, both bilinguals and monolinguals, who have contact influence (cf. Adelaar \& Muysken 2004: 590-591). 
In this article, I consider contact features from a variety of levels of linguistic structure because they all participate in the construction and interpretation of the semiotic field around social categories such as valluno 'local Spanish-dominant speaker' and colla 'Quechua-dominant speaker from the Western highlands'. It is necessary to consider multiple features together because language users perceive sociolinguistic indexes not in isolation, but as part of a pattern of linguistic features that are associated with social groups. In turn, these patterns of sociolinguistic features work together in the construction of a complex system of social categorization. Expectation plays a crucial role in social evaluation.

\section{DATA}

In the following section, I compare and contrast the use of contact features across two social groups: collas, Quechua-dominant speakers from the western highlands; and vallunos, speakers from the local valleys. All the speakers are middle-aged to older women. This is the group in the local context who have had least access to formal educational contexts and who are most tightly linked to traditional lifestyles of agriculture in the countryside.

First, I discuss three speakers who were described to me as collas. This term, often meant to be unflattering, indicates that the speakers are Quechua-dominant immigrants from the western highlands. Lorenza learned Spanish as an adult, after moving with her husband and young children to Iscamayo. She comes from the western highlands of the Cochabamba region, wears pollera, speaks primarily Quechua, and works with her husband in agriculture. Her husband is a fluent bilingual who uses primarily Quechua in the home. Beatriz immigrated from the altiplano with her husband, a highly educated bilingual teacher, and she runs a store on the main street. Most of her social networks are with Quechua speakers, and although her Spanish is fluent, she has notable L2 influence, especially in vowels and prosody. Like Lorenza, she wears pollera, but as a wealthy woman of the altiplano region, the style and cut of her clothes is noticeably different; the fabric is richer and heavier, with several ruffled layers, and the skirt is longer and fuller with layers of petticoats underneath. Emilia is a fully competent bilingual from the Cochabamba valleys who speaks Spanish with her husband and children. She does not wear pollera, but rather the inexpensive pants and skirts of women who are described as de falda 'straight skirt-wearers'. 
Next, I discuss three women who are Spanish-dominant speakers from the local valleys. These women were born and raised in the rural area surrounding Iscamayo, and are identified as vallunos 'valley people', meaning that they are local residents. All three show significant contact influence in their daily speech, but they were never described to me as anything less than perfectly fluent Spanish-speakers. Antonia is in her late seventies and wears pollera. She grew up in a Spanish-speaking household but is a fluent L2 Quechua speaker. She works with her husband in agriculture outside the town of Iscamayo. Braulia, in her late sixties, is a monolingual Spanish-speaker. She wears a straight skirt, and though she lives in the town of Iscamayo, she maintains close ties with the countryside through frequent trips to her estancia, a property in the mountains. Prima, in her fifties, wears a straight skirt and speaks Spanish. She does not speak Quechua, though she understands some. She grew up relatively far away, in a different set of valleys, but she has lived in Iscamayo for all of her adult life. She lives in town and works in agriculture with her husband.

All six of these speakers have considerable Quechua-contact influence in their linguistic performance, yet my consultants characterized colla speakers as unwelcome, unfriendly, and less proficient in Spanish than local speakers. The Quechua contact features in the speech of the local vallunos, on the other hand, is understood to index a local identity and to participate in these speakers' politeness strategies.

\section{Collas: Lorenza}

Lorenza, a Quechua-dominant speaker, learned Spanish as an adult after moving with her husband and young children to Iscamayo. She can be identified as a colla, a bilingual western highlander, by a number of social indexes: she comes from the western highlands, wears pollera 'gathered skirt', speaks primarily Quechua, and works with her husband in agriculture. Her husband is a fluent bilingual who uses primarily Quechua in the home.

Lorenza consistently uses phonetic variants which mark her as an L1 Quechua speaker, in particular, the use of $[w]$ for $/ \beta /$, the $\left[\varphi^{w]}\right.$ variant of $|f|$, stress shift on the lexical item vibóra 'snake' (normatively víbora), and variable vowel height. She has frequent influence from the Quechua threevowel system, and sometimes hypercorrects. Lorenza levels verb paradigms, using the forms entendo, entenden instead of entiendo, entienden, and vienendo for viniendo. Lorenza's speech also shows extensive morphological interference in Spanish, especially in the following areas: (1) grammatical and natural gender categories (2) number, pronouns, and address forms, and (3) verb conjugation. 
Lorenza and I are friends, and we often stop on the street to chat with each other or visit each other's houses. On this occasion, Lorenza and I spoke in her house. She had offered to give me a Quechua lesson, and after speaking for a while in Quechua, we returned to Spanish to continue conversing. In the transcript below, Lorenza explained the differences between Quechua speakers from different regions of Bolivia to me, focusing on the negative characteristics of people from the Cochabamba valleys (she is from Omereque). Only the two of us were present for this conversation.

\section{Transcript 1: Lorenza}

1. S: Más habladoras son. Libre habla todos, están, más feos está hablan. Esos vallunos.

2. A: Aaah, más feos?

3. S: Más feos se está hablan.

4. A: Mmm

5. S: Huuu! Tratan, despues, mmmm! Unas vibóras son.

6. A: (Laughs)

7. S: El Omereques no es.

8. A: Ah ya ya

9. S: No es así.

10. A: Más calladito?

11. S: Más calladito es. El valluno es, huucha, graves son.

12. A: $\mathrm{Hm}$

13. S: Hm. Malas algunas. Si no sabía, enton, después de, vos está, no entendía nada, no ve, el Quechua, no ve, nadita no entende?
1. S: They've got bigger mouths. They all talk excessively, they're, they talk uglier. Those people from the valleys.

2. A: Aaah, uglier?

3. S: They talk uglier.

4. A: Mmmm

5. S: Whuuu! They scold you, then, mmm! They're snakes.

6. A: (Laughs)

7. S: The person from Omereque isn't like that.

8. A: yeah, yeah, yeah

9. S: They're not like that.

10. A: They're quieter [less gossipy]

11. S: They're quieter. The valley person is, whuuu, they're awful.

12. A: $\mathrm{Hm}$

13. S: Hm. Some of them are mean. If you don't know, then, after, you're, didn't understand anything, right, Quechua, right, you don't understand even a little? 


\begin{tabular}{|c|c|}
\hline 14. A: Ah ha, ah ha, & 14. A: Uh-huh, uh-huh \\
\hline $\begin{array}{l}\text { 15. S: Enton pa Ud. nomás está, con } \\
\text { Quechua, }\end{array}$ & $\begin{array}{l}\text { 15. S: Then they [talk] about you, } \\
\text { in Quechua }\end{array}$ \\
\hline 16. A: Ah ha & 16. A: Uh-huh \\
\hline 17. S: Feo tratan! & 17. S: They scold ugly! \\
\hline 18. A: hmmmm! & 18. A: hmmmm! \\
\hline 19. S: Feo tratan! & 19. S: They scold ugly! \\
\hline 20. A: Al que no entiende? & $\begin{array}{l}\text { 20. A: To someone who doesn't } \\
\text { understand? }\end{array}$ \\
\hline 21. S: No entende. & 21. S: Doesn't understand. \\
\hline
\end{tabular}

In this passage, multiple nonstandard features appear, such as nonstandard agreement (line 1,13) and verb conjugation (line 13,21). These features, as well as nonstandard /f/ and stress shift, are in boldface in this transcript. Lorenza uses nonstandard /f/ on the lexical item feo in Lines 1, 17, and 19. In Line 5, she uses penultimate stress marking for the lexical item vibóra 'snake, malicious person'.

Despite the fact that virtually all Spanish speakers use all of these features occasionally, Lorenza is seen as an unskilled speaker because she uses these features frequently, indeed, pervasively, and with no particular sociolinguistic or contextual pattern. Other consultants characterized Lorenza as a poor speaker of Spanish, and their imitations of her speech included her lack of gender and number agreement, gender and number mismatches, and vowel height, all of which are stereotypical characteristics of second-language Spanish speakers. There is no one single feature that marks her as a Quechua speaker. Rather, it is the combination of these features that does so.

\section{Collas: Beatriz}

Beatriz is a merchant. She runs a store on the main road, alongside many similar stores, several of which are also run by highly educated, relatively wealthy bi- or multilingual schoolteachers. She speaks good Spanish, but it seems to be laborious for her, and she has the telltale high pitch of an L1 Quechua-speaking woman ${ }^{5}$. For me, the most notable L2 feature of Beatriz's 
Spanish is her vowel quality; although she consistently distinguishes between high and low vowels, her low vowels are higher than the usual Spanish targets. In addition, as can be seen in Transcript 2, her grammatical constructions are fairly simple. She misses an article before papel 'paper' and interés 'interest' and she uses penultimate stress on the word ultímo, as opposed to normative antepenultimate último. The repetition of cuatro cuatro cuatro cuatro 'four [by] four [by] four [by] four' would also sound more natural in Quechua than in Spanish.

Transcript 2: Beatriz

\section{B (Beatriz), F (Froilán)}

1. B: La palabra, de esa parte yo le he preguntado aquí mas al ultímo ahorita, la, all, a Doña Mariela le he preguntado no ve? Si no vamos a presentar papel cuánto va a ser interés? Un punto mas va a ser más interés, nos dijo, si o no, a ver? Y están escuchando Uds. Yo he preguntado. $\mathrm{Y}$ además en Santa Rosa, no están sacando con papel. Entre ellos se han garantizando, cuatro cuatro cuatro cuatro.

2. F: Pero señora, si vamos a presentar el plano,

3. B: $\mathrm{Si}$, por eso

4. F: Ya está aprobado por el consejo, la directiva nos va a balar

5. B: Claro
1. B: May I have the floor. On this front, I recently asked um, Doña Mariela, I asked her, right? If we're not going to present paper how much will [the] interest be? It will be one point more, she said, yes or no, right? And you are hearing me now. I have asked. And besides in Santa Rosa, they're not getting [loans] with papers. They're guaranteeing among themselves, four four four four.

2. F: But ma'am, if we're going to present the design,

3. B: Right, exactly.

4. F: It's already approved by the council, the officers will [?]

5. B: Of course.

Lorenza, who has an unusually low-pitched voice in Quechua, sounds shrill when she speaks Spanish. 
Beatríz speaks up in a meeting after her husband, the president of the group, comes under heavy fire from audience members regarding the difficulties in the plan for the members of the meeting to get loans for the construction of their houses. In Iscamayo as in much of the Andes, community offices are often ostensibly held by men, but it is tacitly understood that the job involves the combined efforts of a married couple. Beatriz speaks using proper meeting etiquette, but her sentence construction is choppy, and she phrases her first several sentences as questions. An audience member responds, somewhat patronizingly, calling her señora 'ma'am' and patiently reviewing aspects of the deal with her. Beatríz responds defensively in Turns 3 and 5, saying "Right, exactly", and "of course", in response to the insinuation that she does not adequately understand what is going on. As the wife of the leader of this group, it is unlikely that she is unaware of the subtleties of the matter under discussion.

It is unusual for Quechua-dominant bilingual women to speak up in meetings. Beatríz was motivated to do so by a series of highly charged attacks on her husband. In Transcript 2, others frame her contributions as ill-informed and irrelevant, that is, as inappropriate to the meeting setting, at least in part because of her lack of skill in Spanish oratory, as manifested through the contact features in her speech.

\section{Collas: Emilia}

Emilia comes from the rural western highlands. Now in her sixties, she has lived in Iscamayo for most of her life, since she was married as a young woman. Her husband is a Spanish-speaking farmer; they use Spanish in the home, and their grown children are all monolingual Spanish speakers. Emilia commented to me that she grew up speaking Quechua. Her stories show that her father was a bilingual and a person of importance in the community, a landowner with plenty of cattle and an abundance of kin and ritual kin relationships.

While Emilia's Spanish is fluent and easily understandable, she consistently uses enregistered contact features such as the $\left[\varphi^{w]}\right.$ realization of $/ \mathbf{f} /$. Her realization of vowels is irregular; sometimes she raises $o$ and $e$, and sometimes she hypercorrects, lowering $i$ and $u$. These changes are occasional in her speech, occurring in only five sentences over the ten minutes of transcribed conversation. Once or twice, she misses gender marking, referring to esas borrachos 'those (fem.) drunks (masc.)' and una nomás se ha casado 'only one (fem.) has married', using the feminine form of 'one' to refer to her son. 
Transcript 3 shows Emilia employing a high density of enregistered features. She is describing how her father, as ritual godparent to a young married couple, resolved disputes between his ahijados 'godchildren'. Vowel raising or lowering in Turns 1 and 2 is underlined and marked with boldface.

Emilia spoke to me in her home, during an interview that I carried out with her and her husband. Emilia's husband is a distant relative of my husband, who calls him 'uncle', and he knew me well from projects I worked on with him during my Peace Corps service. I knew Emilia a little less well, but she was still comfortable speaking with me and seemed eager to be interviewed. In this interview, we talked mainly about their children and their family history. Emilia's husband, who interpreted our interview as a formal occasion, wanted to talk about the Bible, which he had been studying because of the influence of an evangelical church. Emilia, however, preferred to chat with me informally about her family and her upbringing. In the full transcript, it is clear that there is some tug-of-war between the two to determine which interpretation of our conversation is more appropriate. The three of us sat in their patio chatting, occasionally interrupted by people who came to buy small items from the store they ran out of their home.

Transcript 3: Emilia

\section{E (Emilia), A (Anna)}

1. E: Nosotros sabíamos, como wawas éramos, una pelea se hacía para ahijados carajo. Venieron a quejarse. Como este, este, padrinos, ese es. Yaaa, y le daban con un chicote ellos. A quien que tenía culpa leee wasqueaban ahi. Hacían arrodillar-

2. "Arrodillense ahi! Perdónese de su mujer! Tiene que perdonar de su mujer, porque ha pegado!" $\mathrm{Y}$ así que le perdonaban; ya, primerito tienen que darlo wasca! (laughs)
1. E: We used to, since we were just children, there was a fight between godchildren by golly. They came to complain. How this, this, the godparents, that's it. Yaaa, and they hit him with a whip. Whoever was at fault they whipped him there. They made them kneel-

2. "Kneel here! Beg forgiveness of your wife! You must ask forgiveness of your wife, because [you] hit [her]!" And so they forgave each other; yes, but first they had to be whipped! 
3. Wasca le daban, y después ya hacía perdonar, le hacía abuenar ahi, mi papa, de ahí tiene que haber, lo que sea, aunque sea mote con queso, como a nosotros no nos faltabamos nada, nos faltaba, la este, vacas álla

4. A: ah-ha

5. E: Y queso cada uno, una bola ponía sobre el mote, de ahí tiene que hacer comer el uno al otro, al otro así. Eso era.

6. N: Eso era seguro una forma de

7. E: Abuenarse, claro!

8. N: Reconciliación! (chuckles)
3. They whipped them, and then they were made to forgive each other, they made up to each other there, my father, then there had to be, whatever, even if just corn with cheese, since we never lacked for anything, we lacked, this, cows out there,

4. A: Uh-huh

5. E: And cheese, he put a ball of cheese over the corn, and they had to feed each other, like that. That was the way it was done.

6. N: That must have been a form of,

7. E: Making up, of course!

8. N: Reconciliation! (chuckles)

In Transcript 3, Emilia both narrates and quotes her father dealing with the errant godchildren. She uses loanwords from Quechua such as waska 'whip, rope' (Turn 1, 2), mote 'boiled corn' (Quechua mut 'i, in Turn 3) and wawa 'child, baby' (Turn 1). She uses unusual constructions for Spanish. For example, while she begins with the reflexive se in Perdonese de su mujer 'Beg forgiveness of your wife', the reflexive disappears in the next sentence, Tiene que perdonar de su mujer 'You must ask forgiveness of your wife', and she omits a clitic where one would ordinarily have occurred, porque ha pegado! 'because [you] hit [her]!'(Turn 2). She uses the semantic convergence hacer causative extensively in this excerpt (Turns 1, 3, 5), each time with a different agent. Likewise, her vowel height (underlined and in boldface) is inconsistent throughout the reported dialogue, part of which is reproduced here; at first she raises vowels, then she lowers them. This feature is gradient, and I marked only those instances that were clearly higher or lower than normal Spanish targets. Because this feature is so sociolinguistically salient, and such a strong index of Quechua speakers, even a few occurrences are highly significant, and language users pick up on them quickly.

Turns 7 and 8 are also interesting with respect to the use of contact features. Emilia uses the word abuenarse 'to make up, to make good', 
from the Spanish root bon- 'good'. This word is fairly common in Latin American Spanish, but is not recognized by the Diccionario of the Real Academia Española (DRAE 2001). There is a cluster of Quechua words for 'reconciliation': allitupanakuy, allipanakuy, allinyanakapuy, allinyay. All of these use the root alli- 'good,' usually translated into Spanish as bueno 'good,' and many involve the reflexive verb construction $-k u$, which parallels the Spanish -se in abuenarse. Emilia's husband (N) jumps in to explain that this was a form of reconciliación 'reconciliation', a relatively high-flown vocabulary term. In doing so, he constructs himself as a more educated, elegant speaker than his wife.

Emilia was consistently identified as a colla, a Quechua-speaker, and a migrant from the west by her neighbors in Iscamayo. This evaluation is certainly related to the way she talks; however, it is also a way of expressing antipathy related to petty rivalries with her neighbors. Emilia owns a business selling chicken; her husband is a local farmer. In a separate conversation with a neighbor of Emilia's, the neighbor complained that Emilia's business selling chickens attracted vermin to the area around the house. The neighbor gossiped that she had complained directly to Emilia, and Emilia responded by saying, "If you're so envious of me, then you can support me". The neighbor's interlocutor responded, Colla es pues 'It's that she's a colla'. Through this comment, Emilia's (allegedly) rude and unneighborly behavior is linked to her status as a bilingual from the highlands of Cochabamba.

\section{Collas: Summary}

People who are identified as collas are expected to have L1 Quechua interference, despite their different histories, circles of interaction, and Spanish language abilities, and the three collas I have discussed here meet these local expectations. Lorenza speaks primarily Quechua and has persistent L1 contact features in her speech despite her friendships with Spanish-speakers. Beatriz is a merchant who interacts with her customers in both languages and supports her husband's political role. Finally, Emilia is a highly fluent Spanish-speaker who manipulates the use of contact features to voice different characters in her narrative.

There is a close relationship between classification as a language speaker and evaluation of a person's social worth or appropriate sphere of influence. In comments about these speakers' language abilities, others characterize them not just as poor Spanish speakers, but also as inconsiderate neighbors, and as people who are ignorant of important aspects of political discussions.

A common characterization of the speech of Quechua speakers is that it is atravesado 'crossed', in the sense that logs laid across a stream are crossed at right angles to the main flow of water. The DRAE gives two alternate 
definitions for this term that are relevant to the interpretations of colla speech described here. Atravesado can also mean "having bad intentions or a bad character" or, in the Andes, "mulatto or mestizo". A consultant gave me a polite gloss for the word: "someone who has learned Spanish when they're already grown, who speaks Quechua as a first language". These links between perceived use of language, ethnicity, and character are pervasive in the Andean context.

However, contact features in themselves are not sufficient to show that a speaker is Quechua-dominant, or any of the associated personal characteristics that this entails. In the following sections, many of the same features that I identify in the speech of people who were identified to me as collas appear in the speech of Spanish-dominant speakers who are from the local valleys.

\section{Vallunos: Prima}

Prima is a Spanish-dominant speaker in her sixties. She wears a straight skirt, not a pollera, and she lives in the center of town. Like many women of her age, she was raised in the local rural highlands and moved to Iscamayo as an adult; her husband is a successful farmer who owns valuable farmland near town. Other informants identified Prima as a local, i.e., a person from the valleys, and I never heard her characterized as a poor or inept speaker.

Prima frequently uses contact features in her speech, and I was surprised to learn that she knows no Quechua at all, because an older sister wears pollera and is a fluent bilingual. She uses the $\left[\varphi^{\mathrm{w}}\right]$ variant of /f/ and stress shift quite regularly in relaxed speech, along with loanwords and prosodic features, such as a high $\mathrm{f}_{0}$, that are linked to contact. On separate occasions, she expressed discomfort with speaking in formal situations and reluctance to be recorded (see Babel to appear-a for a more detailed discussion of shame and reluctance in women's language use). This linguistic self-consciousness is clear in the contrast between the two excerpts I present below.

I interviewed Prima on a couple of different occasions during my fieldwork; she was my landlady, as I rented a room in her house, and a family friend of my husband's. We spoke on a daily basis throughout this fieldwork period. In Transcript 4, taken from an interview about language ideologies that I carried out in her kitchen with her husband present, she

6 Retrieved from the Web, 28/7/2014. Diccionario de la Real Academia Española, Vigésima Segunda Edición. http://lema.rae.es/drae/?val=atravesado 
is on her best linguistic behavior, talking about her hope that her children would study English.

Transcript 4: Prima

\section{P (Prima), A (Anna), N (Nicolás, Prima's husband)}

1. P: En cambio yo harto he deseado que mi hija antes entre a estudiar inglés.

2. A: Mhm

3. P: También, Nelly, Nestor, y así como que, allá. Si hay, no ve, para llevar, puro inglés, no ve?

4. A: Hay

5. P: Hay, pues, pa salir $y$, de, profesora de inglés están, no ve?

6. A: Si, si, si. Hay eso.

7. P: Y, ellos, no han tenido interés. Igual el Henry. Ha hecho dos, tres meses, parece, inglés,

8. A: Mhm

9. P: Y de ahí lo ha dejado también. Porque ya también, no podía alcanzar, si,

10. A: M, si.

11. N: M

12. P: Yy, lo ha dejado así. Y, es bien es saber [el in]. De los dos.

13. A: A ha

14. P: Entender.
1. P: On the other hand, I have always wished that my daughter would study English.

2. A: Mm-hmm

3. P: Also, Nelly, Nestor, and so on, over there. There is, isn't there, to study, just English, right?

4. A: There is.

5. P: There is, to graduate and, be an English teacher they're there, right?

6. A: Yes, yes, yes. There is that.

7. P: And they, weren't interested. Henry was the same. He did two, three months, I think, of English,

8. A: Mm-hmm

9. P: And then he stopped too. Because at that point, too, he couldn't [afford], and,

10. A: Mm, yes.

11. N: M

12. P: Aand, so he just stopped. And, it's good to know [En-]. Both.

13. A: Uh-huh

14. P: To understand.

In Transcript 4, Prima uses formal-sounding phrases such as en cambio 'on the other hand' and asi como que 'on the other hand' (Turns 1, 3, underlined). She also uses también twice in Turn 9; también is used and over-used when 
speakers are trying to establish a formal register (Babel 2011). Three aspects of her speech suggest that Prima is monitoring her speech. She is fairly dysfluent; she corrects herself in Turn 12; and she phrases her statements as questions in Turns 3 and 5. In the first line, Prima's $e$ vowel is slightly raised (boldface), but there are no other phonological or morphological contact features in this segment. Later in the conversation she asks me, Usted va a pasar clases alll, a su idioma de Usted, o no? 'Will you [formal] be teaching classes innnn, in your [formal] language, or not?'. The use of the formal person Usted, which she rarely used with me in more casual settings, is one more sign of a formal style of speech, and she draws attention to this by using the explicit pronoun twice in this short sentence. She certainly does not need to use the formal pronoun with me, a much younger woman and a social subordinate. Rather, she uses it to cast herself as a polite and educated person in an effort to live up to the interview context.

Prima varies her use of contact features to fit different situations. In Transcript 5, she makes suggestions about how to improve the cooking stove that she obtained from an NGO. On this occasion, we sat outside near her wood stove, as my husband replaced some metal parts that had deteriorated on the NGO-supplied stove. He was within earshot but did not participate in the conversation. I played the role of a representative of the NGO, running through a cooking-practices questionnaire with her. In Transcript 3, she responded to the question, "How could the stove be improved?"

Transcript 5: Prima

\section{P (Prima), A (Anna)}

1. P: Y yo decía, Anita, sabís que decía?

2. A: Mhm

3. P: Que si no hubiera tenido el ladrillo, fuera solamente el fierro,

4. A: Mhm

5. P: Eso más bien quería yo Anna decir. Que tenga solamente ese fierro, y tenía las patitas, que no tenga el ladrillo para que, tenga más campito adentro! $\mathrm{Si}$ asicito es el campito!
1. P: I was thinking, Anita, you know what I was thinking?

2. A: Uh-huh?

3. P: What if it didn't have the brick, if it were just the metal [ring].

4. A: Uh-huh

5. P: That's what I was thinking, instead, Anna. That it should just have the metal [ring], and the feet, and not the brick so that it, has more space inside! It's this tiny, that space! 
6. A: Mm, ya ya ya ya.

7. P: No ve? Mientras más campito, más ponimos leñita y más bracea, más calda va.
6. A: Mm, yeah, yeah, yeah.

7. P: Right? When there's more space, we put more wood and it burns better, it heats more.

Although Prima has a number of serious complaints about the stoves, she is worried that direct criticisms might be offensive or might place me in a difficult position. She invokes our close relationship through an intimate address form, using the vos conjugation of the verb sabis, the diminutive Anita, and a pronounced $\left[\varphi^{w]}\right.$ in the words fuera and fierro (Turns 3 and 5). She uses the raised-vowel form of sabés [sabis] 'you know' and ponemos [ponimos] 'we know' (Turns 1 and 7). She also uses negative politeness strategies, focusing on the fact that it is "just me" that is giving this advice, using subjunctive verb forms in Turn 3 , and a proliferation of diminutives in Turns 5 through 7: patitas 'little feet', campito 'little space', and leñita 'little sticks'.

Prima uses these features to index a close personal relationship, one that for her is rooted in tradition and in traditional values of respect and politeness. While the features themselves are very similar to those found in the speech of Quechua-dominant speakers, Prima's varying use of contact features over different social contexts is part of her construction as a more skilled speaker; this type of stylistic variation is typical and expected of local Spanish-dominant speakers.

\section{Vallunos: Antonia}

Antonia, a woman in her eighties, lives just outside of town, across the river. She dresses in the traditional, hand-sewn pollera and black fedora-style hat of the valleys. She learned Spanish as a first language in her family home, but she was then raised by a Quechua-speaking aunt after being orphaned as a pre-adolescent. She understands Quechua and can speak it when necessary but says that she does not speak it well, and she speaks exclusively Spanish with her family members. While Antonia's close associates know that she is a Spanish-speaker, people who have seen her about town or know her only casually sometimes expressed surprise to me that she does not consider herself a Quechua speaker. I surmise this has to do with her strong identification with the traditional complex in other aspects of her person, such as her dress and her longtime residence in an area that is considered isolated from Iscamayo. In addition, her heavy use of contact features could lead to this conclusion. 
Antonia uses enregistered phonological contact features including $\left[\varphi^{w]}\right.$ and the $v / w$ alternation. She uses penultimate stress marking more frequently than other speakers I have recorded. As can be seen in Transcript 6, she also uses semantic convergence variables such as pues, también and deciabámos (Turn 1), and she uses the contraction ande (Spanish adónde) in Turn 7, where normative Spanish would have dónde. In Turn 5 she preposes the subject, "Marciana". All these features are linked to the traditional semiotic field through enregisterment.

Antonia is a member of my husband's family. On this occasion, a group of close family members were seated around the kitchen table in my home, preparing to have a meal. Antonia addressed this group of close family members in this excerpt.

Transcript 6: Antonia

A (Antonia), J (Juana), G1 (Gerardo)

1. A: Dirá pues, ella también, "Tu tía es," le deciabámos al finado Germán, que es, el Gabriel.

2. J: Ha a, ha a.

3. A: "Qué va a ser mi tía pues. Qué le voy a decir tía yo. Si yo soy más grande, ella que me esté diciendo tío a mí."

4. G1 \& J: (laughing)

5. A: La Marciana era esa.

6. J: Nunca más se ha sabido esa mujer, no? Otra que no quiere parientes es.

7. A: ¿Ande ha dicho que está? Ha hecho estudiar, en la,

8. G1: No, ha,

9. A: en Belén.
1. A: She must be saying, too, "She's your aunt," we used to say to the deceased Germán, I mean Gabriel.

2. J: Mm-hmm, mm-hmm.

3. A: "I don't believe she's my aunt. I won't say aunt to her. If I'm bigger, she should be saying uncle to me."

4. G1 \& J: (laughing)

5. A: That was Marciana.

6. J: We've never heard anything else about that woman, have we? She's another one that doesn't want relatives.

7. A: Where did they say she is? She studied, in the,

8. G1: No, she-

9. A: In Belén.

The signs that index a person as lower class or "country" and open them to rude treatment and discrimination extend to practically everything about them, including their name. In Transcript 7, the speakers continue talking 
about Marciana, a distant relative who has moved to the city. Juana opens a discussion of name-changing.

Transcript 7: Antonia

J (Juana), A (Antonia), N (Nolán)

1. J: No dizque se llama Marciana ahora, no? Que dizque que se llama?

2. A: Que se-

3. N: $\mathbf{F}\left(\varphi^{w}\right)$ austina se llama ella.

4. A: $\mathbf{F}\left(\varphi^{w}\right)$ austina?

5. J: No es Faust-, Que dice que se llama? Vi-cki, no sé qué dice, ha cambiado de nombre! Ya no es Juliana. No, la Juliana, la Juliana es la que se ha cambiado de nombre. La Marciana creo que sigue nomás con ese nombre.
1. J: Apparently she's not called Marciana now, right? What do they say she's called?

2. A: That she-

3. N: She's called $\mathbf{F}\left(\varphi^{w}\right)$ austina.

4. A: $\mathbf{F}\left(\varphi^{w}\right)$ austina?

5. J: It's not Faust- What is she called? Vi-cki, I don't know what they say, she changed her name! She's not Juliana anymore. No, Juliana, Juliana's the one who changed her name. I think Marciana still has the same name.

In this segment, Antonia's daughter, Juana, ridicules people who try to change their names as a sign of being modern people, making fun of Juliana's transformation into Vicki, a very trendy, almost teeny-bopper kind of name. Nolán, Antonia's adult grandson and Juana's son, jokes that the woman changed her name to Faustina, a name which is even more indexical of old-time country ways than her original name, Marciana. To add color to the joke and emphasize the name's country-ness, he pronounces Faustina with the $\left[\varphi^{w]}\right.$ variant. In Turn 4, Antonia, who uses this variant consistently, misses both the iconic $\left[\varphi^{w]}\right.$ feature and the indexical linkage of the name Faustina to the idea of being traditional, rural, "backwards," and rooted in the countryside; in short, she does not get the joke.

For Antonia, a speaker in her seventies who is strongly oriented to the traditional semiotic complex, using the $\left[\varphi^{w]}\right.$ variant is not an index of anything. By invoking the traditional semiotic complex with his use of $\left[\varphi^{w]}\right.$ on the old-timey name Faustina, Antonia's grandson creates an indexical layer that his mother, but not his grandmother, recognizes and responds to. However, he does not intend to target his grandmother with this joke; while Antonia is a traditionally-oriented older woman with roots in the countryside, her position 
as a native Spanish speaker and close family member exempts her from the negative evaluations that are commonplace for collas.

\section{Vallunos: Braulia}

Braulia is in her seventies, and she lives in the town of Iscamayo, close to her children. However, she continues to own land in the high rural regions surrounding town. Until the year of my fieldwork, when she bowed to pressure from her children and decided she was too old, she used to walk the six to eight hours to visit her estancia on a regular basis. Braulia wears pants and skirts, not pollera, and she is a native speaker of Spanish. She says she does not speak or understand much Quechua. Braulia uses enregistered features such as the $\left[\varphi^{w]}\right.$ variant of $/ f /$ on a regular basis, as in Transcript 8 , where she discusses her (lack of) schooling.

On this occasion, Braulia, another member of my husband's family, had stopped by our house to chat on her way to gather firewood. She took a chair to our patio and spoke at length with my husband and me about her childhood, as children and dogs played at our feet.

Transcript 8: Braulia

\section{B (Braulia), A (Anna)}

1. B: De habilidad era. Igual era yo p.' Con él. Los únicos éramos los dos que sabíamos mascito de eso. De eso la Catoco una vez haya ido él, le dijo, "Por qué no ha puesto a la escuela? Así como yo elay no he aprendido, hace falta." De esa manera le haya, le haya venido [...] un añito nos ha puesto a la escuela. Después otro año ya no ha querido.

2. A: Esos años pues las mujeres no iban, no?
1. B: He was good at it. I was, too. As good as him. We were the only two that were any good at it. About that Catoco once when he went, she said, "Why didn't you put [her] in school? Look at me, I never learned, it's necessary." That's how, he came [...] and he put us in primary school for just one year. Then the next year he wouldn't.

2. A: In those years girls didn't go, did they? 
3. B: No. "Pa qué va a servir?" me dijo. "Pa qué, en qué les va a servir el estudio? No va a servir de nada," nos dijo. Y tanto hace falta. Es como si uno fuera ciego, no? (intake) A mí me da pena y rabia me hace que, que tanto a ver no hemos aprendido. Yo era, de habilidad era.
3. B: No. "What good does it do?" he told me. "For what, what is studying going to do for you? It won't do anything", he told us. And it's so necessary. It's as if one were blind, isn't it? (intake) It makes me so sad and it makes me angry that, that there was so much we never learned. I was, I was good at it.

Throughout the transcript, as on the words falta and fuera in this segment (Turns 1 and 3 , in boldface), Braulia uses the $\left[\varphi^{w]}\right.$ variant of $/ \mathrm{f} /$. She also uses ingressive airflow, a Quechua contact feature, to complement her expression of anger and regret that she was never allowed to go to school (Turn 3).

In Transcript 9, recorded on the same occasion, Braulia begins to tell a story about shepherding her parents' sheep in when she was young; this is typically a job for a pre-adolescent child. She describes her frustration when the vultures came to steal her lambs.

Transcript 9: Braulia

\section{B (Braulia), A (Anna), N (Nolán)}

\begin{tabular}{|c|c|}
\hline $\begin{array}{l}\text { 1. B: La última lomita donde } \\
\text { yo salía a cuidar las owejas } \\
\text { arriiiba, una loma era, ahí el, el } \\
\text { witre me quitaba los corderos. }\end{array}$ & $\begin{array}{l}\text { 1. B: The very last ridge where I } \\
\text { would come out to take care of } \\
\text { the sheep up hiiiiigh, there was } \\
\text { a ridge, the, the vulture would } \\
\text { take the lambs from me. }\end{array}$ \\
\hline 2. A: (laughs) & 2. A: (laughs) \\
\hline 3. B: Cuidando & 3. B: Shepherding \\
\hline $\begin{array}{l}\text { 4. } \mathrm{N} \text { : El condor se come los } \\
\text { corderos. }\end{array}$ & 4. N: The condor eats the lambs. \\
\hline 5. B: Eese condor grande que es, & 5. B: Thaat's it, the big condor. \\
\hline
\end{tabular}

In the sentence reproduced here, she uses [w] in owejas [owejas] (normatively [oßexas]) 'sheep', as well as for witre [Spanish buitre] 'vulture', shown in boldface. This is an especially interesting choice, because the Quechua loanword sucha 'vulture' is in common use in this area. I would suggest that using the Spanish word indexes her Spanish-language family 
background, while using the Quechua phonology indexes the "traditional" activity and setting. In a following turn, my husband substitutes the word condor ${ }^{7}$, which she picks up and uses for the rest of the conversation.

However, the $v / w$ alternation, unlike $\left[\varphi^{w]}\right.$, is relatively uncommon for Braulia. Indeed, later in the same transcript (not reproduced here), she uses the normative allophone of $/ \mathrm{v} /,[\beta]$, in oveja "sheep". These linguistic features contribute to the way that Braulia frames her description of this particular activity, with its strong associations with her past and with the traditional activity of shepherding.

The following segment of the same story, in Transcript 10, also includes abundant enregistered features, such as the Quechua-origin loanword mark' $a$ '[held in] one's arms' (Turn 3) and the -abámos verb form (Turn 9). In addition, Braulia uses ya (Turn 3, 5), causative hacer (Turn 3), and singular mass noun harto oveja 'lots of sheep' (Turn 3,7) in this segment of discourse.

Transcript 10: Braulia

\section{B (Braulia), A (Anna)}

1. B: De mi delante se lo alzaba. El corderito, en su pata lo alzaba y lo llevaba. Balaaaando

2. A: (laughs)

3. B: Iba en su patita así un trecho, de ahí lo largaba al suelo, ya se moría el cordero. Ya yo alzaba, ya no servía ya. Pa que ande. Tenía que llevar en mi mark'a, a la casa hacía llevar. Mi mama me pegaba, p' me decía, por qué no,, si las ovejas eran haarto, desparramadas, p' uno por alla arriba, uno no va a estar en seguida, amontone y amontone!
1. B: Right in front of me he would pick it up. The lamb, with his foot he would pick it up and take it away. Baaaaa-ing.

2. A: (laughs)

3. B: He would have it in his foot like that a little ways, then he would drop it to the ground, the lamb would be ready to die. When I picked it up, it was no good anymore. To walk. I had to carry it in my arms, I would have it taken to the house. My mother hit me, she said, why didn't you,, but there were so many sheep, spread all over the

7 A condor, of course, is not the same animal as a vulture; the speaker goes on to describe the enormous size of these birds, justifying this word choice. 
4. A: Mhm

5. B: Hasta que corríamos enton' no había, estaba leeejos ya, corría, hasta eso el condor venía ya. Ya me quitaba. Grave he sufrido ahí, cuidándoles a esas ovejas. Tanto.

6. A: Hartos eran [entonces]

7. B: Haarto eran. De ahí nos hemos venido, vendido toditas las ovejas. El patrón nos ha vaqueado, de ahí, el patrón era de todo ese terreno ahí. Nos vaqueó el patron. "Váyanse a otro lado", nos ha dicho.

8. A: Por que?

9. B: Es que ya teníamos oveja harto, ganado teniabámos; se molestó de eso. Se molestó de eso. place, one way up there, one can't be right behind, herding and herding!

4. A: Mm-hmm.

5. B: By the time we ran up they were gone, they were far away, I would run, by then the condor would come. He would take them away. I suffered awfully there, taking care of those sheep. So many.

6. A: There were lots [then]

7. B: There were loooots. Then we came this way, sold all the sheep. The landowner ran us off, from there, the owner of all that land up there. The landowner ran us off. "Go somewhere else", he told us.

8. A: Why?

9. B: It's that we had too many sheep, we had cattle; he got angry about that. He got angry about that.

Braulia uses some enregistered features, such as the $\left[\varphi^{w]}\right.$, consistently in her speech. Others, such as the $v / w$ change, she uses selectively. In Transcript 10 , we can observe that Braulia uses increased semantic, morphological, and phonological enregistered features when talking about traditional activities in the past. In Braulia's speech, like Emilia's, there is an emergent, higher level of indexicality that draws on linguistic features to evoke characteristics of her past in the rural countryside. Their interlocutors clearly understand these uses of contact features as an acceptable sociolinguistic strategy, in contrast to their evaluation of Emilia as anti-social or of Beatriz as ignorant. Indeed, my husband, a local Spanish-dominant speaker, suggested that I record this conversation as a historical record of the olden days. 


\section{Vallunos: Summary}

In this section, I have described the way that three speakers use enregistered features to mark traditional activities, to voice speakers from the past, and to manage a polite, intimate register in contrast to a formal one. These speakers are all older women, much like the colla women described in the previous section. Their use of contact features is somewhat different from that of the colla speakers, however. For example, there are relatively few examples of morphological contact influence. However, these women and the colla women use contact features in similar ways. Antonia, like Lorenza, seems to be unaware of the indexical value that the phonological contact features she produces have for other listeners. Braulia, like Emilia, uses contact features in order to invoke a time and an activity in the rural past. The major difference is in the uptake, or anticipated uptake from the audience. While Emilia is characterized as a poor speaker and a poor neighbor in part because of her use of contact features, Prima uses contact features in order to construct a polite relationship. While Beatriz is framed as a person who has no business speaking in a meeting, Braulia's audience listens to her attentively and suggests that her narrative should be recorded for posterity.

In the case of local valley speakers, unlike the Quechua speakers, contact features become reinterpreted as enregistered features or indexes of a traditional orientation. They are not linked with a lack of ability or a lack of neighborliness; quite the reverse. They are used by speakers and understood by their interlocutors to index the complex that includes rural life, women's sphere, traditional crafts and occupations. The meanings attached to these features is not pre-determined and common across all contexts and speakers, but rather comes out of contrast with typical patterns of use for particular speakers and groups.

\section{CONCLUSION}

In this article, my central claim is that social meaning, in particular, the value of linguistic indexes as markers of social categories, is produced in relationship with context. I situate this work in relationship to sociolinguistic studies that hold that language use is a creative practice in which speakers not only respond to identity categories but also actively engage in creating and interpreting those social categories. In this process of interpretive work, signs are meaningful only in relation to the context in which they are 
produced. This context includes language users' pre-existing notions about the social categories to which particular speakers belong, and it affects the interpretation that listeners give to any particular instance of linguistic practice. I argue that context is essential to producing and interpreting social meaning, in language as in other symbolic systems.

Throughout this article, I have used the concepts of the semiotic field, indexicality, and enregisterment to discuss the place of contact features in a linguistic landscape. These theoretical concepts offer a useful way to approach variation in Spanish in particular and in situations of language contact in general. A key contribution of this work is to consider language use not just in terms of the production of linguistic features, but also in terms of perceptions and interpretations of language use in the community. Indeed, the social context of the community and the beliefs held by language users are an essential element of analysis in this work.

Much of the existing literature that has used the theoretical concepts I reference has focused on North America, on higher education, or on large urban areas, such as Lima, Peru. In this article, I have brought these concepts to bear on rural Bolivia. Holding age, class, and gender constant, I have compared the language use of Quechua-dominant vs. Spanish-dominant women, and how their actions are interpreted within the larger field of social meaning that is produced in the local area. This is important, since systems of interpretation may work very differently in different types of cultural systems.

There is no single contact feature or even group of contact features that distinguishes the linguistic practice of collas 'Western highlanders' from local vallunos 'people from the Santa Cruz valleys'. Rather, it is a combination of large-scale patterns of language use and, especially, social expectations and stereotypes about language users that guide the interpretation of any given feature for a particular interaction in a particular context. The incidence of linguistic features varies over social contexts and social groups, and speakers learn language not with or in, but as context. In this sense, variationist studies that examine the correlations between language use and pre-determined social categories are essential in that they give us an idea of the kinds of patterns that language users encounter when they form expectations about the relationship between linguistic features and social groups. This study takes up where previous studies leave off, by examining the way that subtle differences in these patterns can affect a listener's perception of particular speakers or of particular instances of speech.

While context is important when we consider all kinds of linguistic signs, it is especially salient when we talk about contact features. Contact features work as part of a larger system that brings together large-scale 
ideologies about language and particular instances of language use by particular speakers. Traditionally, scholars have thought of language contact as focusing on the interaction between linguistic elements that have origins in different language systems, with different political and historical antecedents. However, when we shift our focus to the situated use of language by speakers, we must see these linguistic elements as a set of resources that speakers use in order to position themselves with respect to social categories. Finally, we must attend not only to the way that people speak, but also to the way that their speech is taken up and interpreted. In the data I have presented in this article, a contact feature's meaning depends not only on the history and associations related to that feature, but also on the history and positioning of the speaker who uses that feature. Like other sociolinguistic indexes, contact features require context to "fill in the blanks".

In Iscamayo, as in any part of the world, there is no single template of speech into which features "fit"; likewise, there is no single meaning associated with the use of contact features, outside their use in concrete interactions by particular individuals as representatives of particular social groups. Speakers form expectations about typical distributions of linguistic features, but more than that, the interpretations of these patterns are highly context-dependent and produced through micro-level interactional dynamics. People are not exposed to "language", but to particular communicative situations, and their linguistic competence reflects their experience not only with language, but also with contexts and interlocutors.

\section{REFERENCES}

Adelaar, Willem \& Peter Muysken. 2004. The Languages of the Andes. Cambridge/New York: Cambridge University Press.

AgHA, AsIF. 2000. Register. Journal of Linguistic Anthropology 9: 216-219.

2004. Registers of Language. In Alessandro Duranti (ed.). A Companion to Linguistic Anthropology, 23-45. New York/Oxford: Blackwell.

2005. Voice, footing, enregisterment. Journal of Linguistic Anthropology 15: 38-59. 2007. Language and Social Relations. New York: Cambridge University Press.

Albó, XAVIER. 1970. Social Constraints on Cochabamba Quechua. Dissertation, Cornell University.

Ambadiang, Théophile, Isabel García Parejo \& Azucena Palacios. 2009. Discursos, rutinas comunicativas, y construcción de la identidad en situación de contacto dialectal: el caso de los adolescentes ecuatorianos en Madrid. In Julio Calvo Pérez \& L. Miranda (eds.). Palabras fuera del nido: vertientes sincrónica y diacrónica del español en contacto, 6788. Lima: Universidad San Martín de Porres. 
Babel, Anna M. 2010. Contact and Contrast in Valley Spanish. Dissertation, University of Michigan.

2011. Why don't all contact features act alike? Contact features as enregistered features. Journal of Language Contact 4: 56-91.

to appear-a. Silence as Control: Shame and self-consciousness in sociolinguistic positioning. In Anna Babel (ed.). Awareness and Control in Sociolinguistic Research. Cambridge/New York: Cambridge University Press.

to appear-b. Time and reminiscence in contact: Dynamism and stasis in contactinduced change. Spanish in Context.

Bergholdt, Anders. 1999. Cambas y collas: un estudio sobre identidad cultural en Santa Cruz de la Sierra, Bolivia. Aarhus: Centro de Estudios Latinoamericanos, Universidad de Aarhus.

Bucholtz, Mary \& Kira Hall. 2004. Language and Identity. In Alessandro Duranti (ed.). The Blackwell Companion to Linguistic Anthropology, 369-395. Malden, MA: Blackwell.

Calvo Pérez, Julio. 2000. Partículas en el castellano andino. In Julio Calvo Pérez (ed.). Teoría y práctica del contacto: El español en América en el candelero, 73-112. Madrid: Iberoamericana/Vervuert.

2008. Perú. In Azucena Palacios (ed.). El español en América: contactos lingüísticos en Hispanoamérica, 189-210. Barcelona: Ariel.

Cerrón-PAlomino, Rodolfo. 2003. Castellano andino: aspectos sociolingüísticos, pedagógicos y gramaticales. Lima: Pontificia Universidad Católica del Perú.

Coronel-Molina, Serafin M. \& Linda L. Grabner-Coronel. 2005. Lenguas e identidades en los Andes: perspectivas ideolólogicas y culturales. Quito: Editorial Abya Yala.

De Granda, Germán. 2001. Estudios de lingüistica andina. Lima: Pontificia Universidad Católica del Perú.

De los Heros, Susana. 1999. Prestigio abierto y encubierto: las actitudes hacia las variantes del castellano hablado en Perú. Revista de Humanidades: Tecnológico de Monterrey 6: 13-44.

2001. Discurso, identidad y género en el castellano peruano. Lima: Pontificia Universidad Católica del Perú.

De los Heros, Susana \& Cecilia Montes. 2008. Una primera aproximación al habla de contacto en dos peluquerías limeñas. Oralia 11: 169-190.

DRAE 2001 = Real Academia Española. 2001. Diccionario de la lengua española. 22. ${ }^{a}$ edición. Madrid: Espasa.

Eckert, Penelope. 2000. Linguistic Variation as Social Practice: The Linguistic Construction of Identity in Belten High. Oxford: Blackwell.

2008. Variation and the indexical field. Journal of Sociolinguistics 12: 453-476.

2012. Three waves of variation study: The emergence of meaning in the study of sociolinguistic variation. Annual Review of Anthropology 41: 87-100.

Escobar, AlberTo. 1976. Bilingualism and dialectology in Peru. International Journal of the Sociology of Language 9: 85-96.

Escobar, Anna María. 1988. Hacia una tipología del bilingüismo en el Perú. Lima: Instituto de Estudios Peruanos.

1992. El español bilingüe: semejanzas y diferencias en el uso del posesivo. Lexis 16: $189-222$.

1994. Andean Spanish and Bilingual Spanish: Linguistic Characteristics. In P. Cole, G. Hermon \& D. Martin (eds.). Language in the Andes, 51-71. Newark, Delaware: Center for Latin American Studies, University of Delaware.

1998. Las relaciones hablante-enunciado y hablante-oyente como fuerzas discursivas en el español en contacto con el quechua. Paper presented to the Estudios de lengua y 
cultura amerindias II: lenguas, literaturas y medios: actas de las IV Jornadas Internacionales de Lenguas y Cultura Amerindias, Valencia.

2000. Contacto social y lingüístico: el español en contacto con el quechua en el Perú. Lima: Pontificia Universidad Católica del Perú.

Firestone, Amy. 2013. Quechua and Spanish in the urban Andes: A study on language dynamics and identity construction among Peruvian youth. Dissertation, University of Illinois at Urbana-Champaign.

Godenzzi, JuAn Carlos. 2005. En las redes del lenguaje: Cognición, discurso, y sociedad en los Andes. Lima: Universidad del Pacífico.

2008. Trazas lingüísticas y discursivas de la ciudad: el caso de Lima. Tinkuy 9: 47-64.

2011. Ecología lingüística en procesos urbanos: Tres hablantes del español de Lima. Paper presented at the ALFAL, Alcalá de Henares, Spain.

Gutiérrez Marrone, NiLA. 1980. Estudio preliminar de la influencia del quechua en el español estándar de Cochabamba, Bolivia. In G. Scavnicky (ed.). Dialectología hispanoamericana: estudios actuales, 58-93. Washington: Georgetown University Press.

Howard, Rosaleen. 2007. Por los linderos de la lengua: Ideologías lingüisticas en los Andes. Lima: Instituto de Estudios Peruanos.

Hurtado, Alfonso Román. 2005. Cambas y Collas: Los Paradigmas de una Nueva Nación. Santa Cruz: A. Román Hurtado.

Klee, Carol A. 1996. The Spanish of the Peruvian Andes: The influence of Quechua on Spanish language structure. In Ana Roca \& John B. Benson (eds.). Spanish in Contact, 73-91. Somerville, Massachusetts: Cascadilla.

KuIPERs, Joel. 1998. Language, Identity, and Marginality in Indonesia. Cambridge: Cambridge University Press.

Labov, William. 1972a. On the mechanism of linguistic change. In John Gumperz \& Dell Hymes (eds.). Directions in Sociolinguistics, 512-538. New York: Holt, Rinehart, \& Winston.

1972b. Sociolinguistic Patterns. Philadelphia: University of Pennsylvania Press.

LIPSKI, John M. 2004. El español de américa. Madrid: Cátedra.

Martínez, Angelita (ed.). 2009. El entramado de los lenguajes. Buenos Aires: La Crujía Ediciones.

Mendoza, José G. 2008. Bolivia. In Azucena Palacios (ed.). El español en América: contactos lingüísticos en Hispanoamérica, 213-236. Barcelona: Ariel.

Milroy, James \& Lesley Milroy. 1997. Network structure and linguistic change. In Nicolas Coupland \& Adam Jaworski (eds.). Sociolinguistics: A reader and coursebook, 199-211. New York: St. Martin's Press.

Muntendam, AntJe. 2011. Focus, intonation, and language contact: A case study of Andean Spanish. Paper presented at the Frecuencia, cambio, y contacto lingüístico. El caso del español de los Andes, Freiburg, Germany.

Pfänder, Stefan, Juan Ennis, Mario Soto Rodríguez y España Villegas Pinto. 2009. Gramática Mestiza: Presencia del quechua en el castellano boliviano. La Paz: Academia Boliviana de la Lengua / Editorial Signo.

RAMPTON, BEN. 1995. Language crossing and the problematisation of ethnicity and socialization. Pragmatics 5: 485-513.

SÁnchez, Liliana. 1996. Word Order, Predication, and Agreement in DPs in Spanish, Southern Quechua and Southern Andean Bilingual Spanish. In Karen Zagona (ed.). Grammatical Theory and Romance Languages, 209-218. Amsterdam: John Benjamins.

2004. Functional Convergence in the Tense, Evidentiality and Aspectual Systems of Quechua Spanish Bilinguals. Bilingualism: Language and Cognition 7: 147-162. 
Silverstein, Michael. 2003. Indexical order and the dialectics of sociolinguistic life. Language and Communication 23: 193-229.

StANFORD, JAmES N. 2009. Clan as a sociolinguistic variable: Three approaches to Sui clans. In James N. Stanford \& Dennis R. Preston (eds.). Variation in Indigenous Minority Languages, 463-84. Amsterdam/Philadelphia: John Benjamins.

Stearman, Allan McLean. 1987. Camba y Colla: Migración y Desarrollo en Santa Cruz, Bolivia. La Paz: Librería Editorial "Juventud".

ZaVALA, VIRGINIA. 2011. Racialization of the bilingual student in higher education: A case from the Peruvian Andes. Linguistics and Education 22: 393-405. 